\title{
Genetic Variability Study for Yield and Associate Characters in Early Maturing Sugarcane
}

\author{
Praveen Kumar ${ }^{1 *}$, S.S. Pandey ${ }^{2}$, Balwant Kumar ${ }^{3}$, D.N. Kamat ${ }^{4}$ and Mahesh Kumar ${ }^{5}$ \\ ${ }^{1}$ Department of Plant Breeding and genetics, ${ }^{2}$ Department of SMCA, \\ Dr. Rajendra Prasad Central Agricultural University, Pusa-848125 (Bihar) India \\ *Corresponding author
}

\section{A B S T R A C T}

Keywords

Sugarcane,

Variability, PCV, GCV, Heritability, Genetic advance

Article Info

Accepted:

24 June 2018

Available Online:

10 July 2018
An experiment was conducted with 15 early maturing sugarcane clones to study the genetic variability for yield and associated characters. The analysis of variance revealed highly significant differences among the clones for all twenty three characters. The Variability studies showed moderate estimates of GCV and PCV for traits viz., germination percent, cane diameter at harvest, pol percent in juice at 8 month stage, CCS percent at 8 month, sugar yield and cane yield at harvest. In present set of materials high heritability with high genetic advance as per cent of mean was found in germination percent, cane diameter at harvest, pol in juice at 8 month stage, CCS at 8 month and sugar yield at harvest while high heritability with moderate genetic advance as percent of means was observed for plant height at 240 days and at harvest single cane weight, number of shoots, single cane weight, millable cane at harvest, brix percent at 8 month, CCS at 10 month and cane yield at harvest, indicating the role of dominant genetic effects in determination of these characters and its improvements in early maturing sugarcane clones.

\section{Introduction}

Modern cultivated sugarcane (Saccharum officinarum L.) is a complex inter specific hybrid of five different species of Saccharum genus. Sugarcane belongs to the Poaceae family and is normally propagated by stem cuttings (Khan et al., 2013). Sugarcane is a perennial, tropical; monocotyledonous crop which is cultivated in tropical and subtropical region of the world primarily for its ability to store high concentration of sugar in the inter-node. It is an important sugar and cash crop of India. The scope of the sugarcane can't be overlooked by the farming community as it plays a remarkable role in the economic uplift of the growers. It is essential to have basic information on the genetic nature of variation of various metric traits in sugarcane crops for the proper planning of breeding strategies. The heterozygous and polyploid nature of this crop has resulted in generation of greater genetic variability. The extent of genetic variability present in any crop is of paramount importance for its improvement. The information on the nature 
and the magnitude of variability present in the genetic material is of prime importance for a breeder to initiate any effective selection program. Genotypic and phenotypic coefficients of variation along with heritability as well as genetic advance are very essential to improve productive trait of sugarcane because this would help in knowing whether or not the desired objective can be achieved from the material (Tyagi and Singh, 1998). The knowledge of nature and extent of genetic variation available in the germplasm or breeding material helps the breeder for planning sound breeding programmes. Therefore, present investigation was formulated to study the genetic variability for yield and associated characters in early maturing sugarcane clones.

\section{Materials and Methods}

The experimental materials were early maturing fifteen sugarcane clones namely CoSe 11451, CoSe 12451, CoLk 12207, CoLk 12208, CoP 11436, CoP 11438, CoP 12436, CoP 12437, CoP 13436, CoP 13437, CoP 16436, CoP 16437, CoP 16438, BO 153, CoP 11437 which were planted at regional research station Madhopur west champaran, Bihar, in a Randomized Block Design with three replications in spring 2016. Observations were record by selecting five random plants per genotype per replication for productive characters namely, germination \% at 45 DAP, number of shoots at 120 DAP, plant height at 150,240 and 300 days, cane diameter at harvest, number of millable canes, brix, pol, purity $\%$, extraction, fibre, CCS at 8 and 10 month stages, Pol in cane at harvest, single cane weight, sugar yield and cane yield at harvest.

\section{Brix percent}

It is a measure of total soluble solids present in the juice. It was taken directly by using a
Brix hygrometer . $250 \mathrm{ml}$ juice was taken in measuring cylinder and hygrometer was dipped into the juice then reading was recorded from the juice level . These readings were corrected to the temperature at $20^{\circ}$ by using temperature correction chart as described by Spencer and Meade (1955).

\section{Pol in juice}

Pol refers to the sucrose per cent in juice. It was done according to the method described by Spencer and Meade (1955). It was estimated with the help of Polari scope. First $100 \mathrm{ml}$ juice was taken in conical flask and 4 gm Honey dry lead sub acetate was added and mixed well by shaking the flask. After few minutes this solution was filtered twice through a dry Whatsman no. 1 filter paper and the abstract was collected into a clean and dry beaker. The abstract poured into the Polari meter tube. These tubes were placed in the Polari scope. Thereafter Pol values were recorded by polarising the clear juice in Polari scope this value called dial reading. Sucrose per cent in juice was obtained by referring the brix and dial reading to Schmitz's table.

\section{Purity}

Purity percent of juice $=$

Sucrose per cent in juice x 100 Corrected brix

\section{Extraction per cent}

Five canes from each plot were taken at 8 and 10 month stage and weighed. Juice was extracted with the help of power juice extractor and weighed juice extraction percentage was calculated with the help of following formula:

$$
\text { Juice extraction } \%=\frac{\text { Weight of juice }}{\text { Weight of cane }} \times 100
$$




\section{CCS percent}

$\mathrm{CCS} \%$ is determined by formula

$[\mathrm{S}-(\mathrm{B}-\mathrm{S}) \times 0.4] \times 0.73$

Where,

$\mathrm{S}=$ Sucrose percent in juice (pol \%).

$\mathrm{B}=$ Brix percent in juice.

The data were statistically analyzed. The analysis of variance (ANOVA) was worked out according to the procedure of Randomized Block Design for each character as per methodology advocated by Panse and Sukhatme (1967). The analysis of variance was used to derive variance components (Cochran and Cox, 1957).

\section{Estimation of genotypic and phenotypic coefficient of variation}

The formulae used to calculate PCV and GCV were given by Burton and De vane (1953).

\section{Heritability (Broad sense)}

Heritability in broad sense was estimated by the formula given by Johnson et al., (1955). The heritability was categorized as low, moderate and high as given by Robinson et al., (1949).

\section{Genetic advance}

The estimates of genetic advance were obtained by the formula given by Lush (1949), Johnson et al., (1955) and Allard (1960).

The range of genetic advance is classified as suggested by Johonson et al., (1955). Observed data for all the traits of 15 early maturing sugarcane clones were assessed for statistical analysis.

\section{Results and Discussion}

Variability is measure by estimation of genotypic and phenotypic variance, genotypic and phenotypic coefficient of variation (GCV and PCV), heritability, genetic advance and genetic advance as per cent of mean. These parameters help in selection for improvement of desired characters. Environment plays an important role in the expression of phenotype. The phenotypic variability which is observable includes both genotypic (heritable) and environmental variation (non-heritable).

The mean sum of square due to treatments was found highly significant for all the traits these traits exhibit significant differences (Table 1). Thus, it implied that there is reasonably sufficient variability in material used for their study, which provides ample scope for selecting superior and desire clone by the plant breeder for further improvement. Earlier workers Doule and Balasundaram (2003), Singh et al., (2010) reported high variability for different traits in sugarcane. To decipher the amount of existing variability in the present clones, range, mean and standard error were calculated (Table 2) However, range is the crude method of estimation of variability, which indicates observed phenotypic variability only. It also showed the advisable range of co-efficient of variation for all the traits. From the perusal of the (Table 3), it is observed that phenotypic variances for all the characters under study are higher than genotypic variances. Similar result was reported by (Praveen et al 2017). This may be due to the non-genetic factor which played an important role in the manifestation of these characters. Comparatively the maximum phenotypic and genotypic variances were exhibited by the traits viz. plant height, cane yield at harvest, number of millable canes, number of shoots at 120 DAP. These findings were in accordance of Ravishankar et al., (2004) for cane yield/ plot and number of 
millable cane/ plot. The numerical value of phenotypic coefficient of variation is higher than their genotypic counterpart indicating that apparent variation is not only due to genotypes but also due to influence of environment. The narrow difference between PCV and GCV were recorded for most of the traits. Moderate GCV and PCV was observed for the characters namely germination percent, cane diameter at harvest, pol percent in juice at 8 month stage, CCS percent at 8 month, sugar yield and cane yield at harvest. The $\mathrm{PCV}$ and GCV of remaining traits were comparatively of lower magnitude. The high heritability in broad sense was recorded for all the characters except plant height at 150 days and purity at 10 month where it was moderately heritable. While germination percent, cane diameter at harvest, pol in juice at 8 month stage, CCS at 8 month and sugar yield at harvest exhibited high genetic advance as per cent of mean and single cane weight, plant height, number of shoots, single cane weight, millable cane at harvest, brix percent at 8 month and CCS at 10 month and cane yield at harvest showed moderately genetic advance as per cent of mean.

Table 1: Analysis of variance for twenty three traits of early maturing sugarcane clones

\begin{tabular}{|c|c|c|c|c|}
\hline \multirow[t]{2}{*}{ Sl. No. } & \multirow[t]{2}{*}{ Character } & \multicolumn{3}{|c|}{ Mean sum of square } \\
\hline & & Replication (d.f. $=2$ ) & Treatment $($ d.f. $=14)$ & Error (d.f. $=28)$ \\
\hline 1 & Germination $\%$ at 45 DAP & 10.82 & $50.07 * *$ & 4.51 \\
\hline 2 & Shoots at 120 DAP (000/ha) & 33.80 & $242.19 * *$ & 33.28 \\
\hline 3 & Plant height at 150 DAP $(\mathrm{cm})$ & 16.45 & $267.82 * *$ & 51.15 \\
\hline 4 & Plant height at 240 DAP $(\mathrm{cm})$ & 39.04 & $617.55 * *$ & 96.87 \\
\hline 5 & Plant height at harvest (cm) & 7.39 & $1321.21 * *$ & 179.38 \\
\hline 6 & Cane diameter at harvest $(\mathrm{cm})$ & 0.003 & $0.253 * *$ & 0.011 \\
\hline 7 & Single cane weight at harvest $(\mathrm{Kg})$. & 0.001 & $0.021 * *$ & 0.001 \\
\hline 8 & Millable canes at harvest $(000 / \mathrm{ha})$. & 25.65 & $205.21 * *$ & 22.47 \\
\hline 9 & Brix at 8 months stage $(\%)$ & 0.36 & $5.77 * *$ & 0.41 \\
\hline 10 & Pol in juice at 8 months stage $(\%)$ & 0.11 & $9.33 * *$ & 0.26 \\
\hline 11 & Purity at 8 months stage $(\%)$ & 12.89 & $69.88 * *$ & 7.83 \\
\hline 12 & Brix at 10 months stage $(\%)$ & 0.03 & $1.66 * *$ & 0.10 \\
\hline 13 & Pol in juice at 10 months stage $(\%)$ & 0.03 & $2.41 * *$ & 0.25 \\
\hline 14 & Purity at 10 months stage $(\%)$ & 1.25 & $17.02 * *$ & 4.16 \\
\hline 15 & Extraction at 8 months stage (\%) & 0.60 & $17.15 * *$ & 0.28 \\
\hline 16 & Extraction at 10 months stage $(\%)$ & 0.76 & $15.33 * *$ & 0.52 \\
\hline 17 & Fibre at 8 months stage $(\%)$ & 0.16 & $0.70 * *$ & 0.06 \\
\hline 18 & Fibre at 10 months stage $(\%)$ & 0.004 & $0.435 * *$ & 0.058 \\
\hline 19 & CCS at 8 months stage (\%) & 0.15 & $6.07 * *$ & 0.19 \\
\hline 20 & CCS at 10 months stage (\%) & 0.03 & $1.59 * *$ & 0.20 \\
\hline 21 & Pol In cane at harvest $(\%)$ & 0.02 & $1.68 * *$ & 0.17 \\
\hline 22 & Sugar yield at harvest ( $\mathrm{t} / \mathrm{ha}$ ) & 0.39 & $6.43 * *$ & 0.74 \\
\hline 23 & Cane yield at harvest (t/ha) & 24.55 & $269.35 * *$ & 41.03 \\
\hline
\end{tabular}

* Significant at 5\%, ** significant at 1\% DAP - Days After Planting 
Table.2 Mean, range and coefficient of variance for twenty three traits of early maturing sugarcane clones

\begin{tabular}{|c|c|c|c|c|c|}
\hline \multirow[t]{2}{*}{ Sl. No. } & \multirow[t]{2}{*}{ Character } & \multirow[t]{2}{*}{ Mean \pm SEM } & \multicolumn{2}{|c|}{ Range } & \multirow[t]{2}{*}{ C.V. } \\
\hline & & & Max. & Min. & \\
\hline 1 & Germination $\%$ at 45 DAP & $34.42 \pm 1.23$ & 39.33 & 25.00 & 6.17 \\
\hline 2 & Shoots at $120 \mathrm{DAP}(000 / \mathrm{ha})$ & $100.33 \pm 3.33$ & 109.67 & 80.00 & 5.75 \\
\hline 3 & Plant height at 150 DAP $(\mathrm{cm})$ & $99.00 \pm 4.13$ & 115.93 & 84.27 & 7.22 \\
\hline 4 & Plant height at 240 DAP $(\mathrm{cm})$ & $179.36 \pm 5.68$ & 201.33 & 157.63 & 5.49 \\
\hline 5 & Plant height at harvest $(\mathrm{cm})$ & $254.87 \pm 7.73$ & 286.33 & 217.83 & 5.25 \\
\hline 6 & Cane diameter at harvest $(\mathrm{cm})$ & $2.23 \pm 0.06$ & 2.77 & 1.73 & 4.66 \\
\hline 7 & Single cane weight at harvest $(\mathrm{Kg})$. & $0.85 \pm 0.02$ & 1.01 & 0.73 & 4.55 \\
\hline 8 & Millable canes at harvest $(000 / \mathrm{ha})$. & $97.23 \pm 2.74$ & 107.69 & 82.08 & 4.87 \\
\hline 9 & Brix at 8 months stage (\%) & $16.30 \pm 0.37$ & 19.53 & 14.00 & 3.91 \\
\hline 10 & Pol in juice at 8 months stage (\%) & $13.46 \pm 0.29$ & 16.97 & 10.21 & 3.78 \\
\hline 11 & Purity at 8 months stage (\%) & $82.36 \pm 1.62$ & 88.37 & 72.96 & 3.40 \\
\hline 12 & Brix at 10 months stage (\%) & $18.44 \pm 0.18$ & 19.67 & 17.20 & 1.73 \\
\hline 13 & Pol in juice at 10 months stage (\%) & $16.14 \pm 0.29$ & 17.60 & 14.25 & 3.07 \\
\hline 14 & Purity at 10 months stage (\%) & $87.49 \pm 1.18$ & 90.97 & 82.67 & 2.33 \\
\hline 15 & Extraction at 8 months stage (\%) & $53.96 \pm 0.30$ & 57.60 & 51.18 & 0.98 \\
\hline 16 & Extraction at 10 months stage (\%) & $55.87 \pm 0.42$ & 58.93 & 52.83 & 1.29 \\
\hline 17 & Fibre at 8 months stage (\%) & $14.52 \pm 0.14$ & 15.23 & 13.27 & 1.64 \\
\hline 18 & Fibre at 10 months stage (\%) & $12.94 \pm 0.14$ & 13.64 & 12.35 & 1.87 \\
\hline 19 & CCS at 8 months stage (\%) & $9.00 \pm 0.25$ & 11.64 & 6.34 & 4.83 \\
\hline 20 & CCS at 10 months stage (\%) & $11.11 \pm 0.26$ & 12.25 & 9.53 & 4.03 \\
\hline 21 & Pol In cane at harvest (\%) & $13.25 \pm 0.24$ & 14.53 & 11.67 & 3.12 \\
\hline 22 & Sugar yield at harvest (t/ha) & $9.17 \pm 0.50$ & 12.34 & 7.59 & 9.36 \\
\hline 23 & Cane yield at harvest (t/ha) & $82.21 \pm 3.70$ & 100.85 & 69.58 & 7.79 \\
\hline
\end{tabular}


Table.3 genetic parameters for twenty three traits of early maturing sugarcane clones

\begin{tabular}{|c|c|c|c|c|c|c|c|}
\hline Sl. No & Characters & $\sigma^{2} G$ & $\sigma^{2} \mathrm{P}$ & GCV & PCV & $\mathrm{h}^{2}(\mathrm{bs})$ & GA M \\
\hline 1 & Germination $\%$ at 45 DAP & 15.19 & 19.70 & 11.32 & 12.89 & 77.09 & 20.48 \\
\hline 2 & Shoots at $120 \mathrm{DAP}(000 / \mathrm{ha})$ & 69.64 & 102.91 & 8.32 & 10.11 & 67.67 & 14.09 \\
\hline 3 & Plant height at 150 DAP $(\mathrm{cm})$ & 72.22 & 123.38 & 8.58 & 11.22 & 58.54 & 13.53 \\
\hline 4 & Plant height at 240 DAP $(\mathrm{cm})$ & 173.56 & 270.43 & 7.34 & 9.17 & 64.18 & 12.12 \\
\hline 5 & Plant height at harvest $(\mathrm{cm})$ & 380.61 & 559.99 & 7.65 & 9.28 & 67.97 & 13.00 \\
\hline 6 & Cane diameter at harvest $(\mathrm{cm})$ & 0.08 & 0.09 & 12.76 & 13.58 & 88.24 & 24.69 \\
\hline 7 & Single cane weight at harvest $(\mathrm{Kg})$. & 0.006 & 0.008 & 9.56 & 10.59 & 81.52 & 17.79 \\
\hline 8 & Millable canes at harvest $(000 / \mathrm{ha})$. & 60.91 & 83.38 & 8.03 & 9.39 & 73.06 & 14.13 \\
\hline 9 & Brix at 8 months stage (\%) & 1.79 & 2.19 & 8.21 & 9.09 & 81.48 & 15.26 \\
\hline 10 & Pol in juice at 8 months stage (\%) & 3.02 & 3.28 & 12.92 & 13.46 & 92.11 & 25.54 \\
\hline 11 & Purity at 8 months stage (\%) & 20.68 & 28.52 & 5.52 & 6.48 & 72.53 & 9.69 \\
\hline 12 & Brix at 10 months stage $(\%)$ & 0.52 & 0.62 & 3.90 & 4.27 & 83.53 & 7.35 \\
\hline 13 & Pol in juice at 10 months stage (\%) & 0.72 & 0.97 & 5.26 & 6.09 & 74.56 & 9.36 \\
\hline 14 & Purity at 10 months stage (\%) & 4.29 & 8.45 & 2.37 & 3.32 & 50.76 & 3.47 \\
\hline 15 & Extraction at 8 months stage (\%) & 5.63 & 5.90 & 4.40 & 4.50 & 95.27 & 8.84 \\
\hline 16 & Extraction at 10 months stage (\%) & 4.94 & 5.46 & 3.98 & 4.18 & 90.46 & 7.79 \\
\hline 17 & Fibre at 8 months stage (\%) & 0.22 & 0.27 & 3.19 & 3.59 & 79.05 & 5.85 \\
\hline 18 & Fibre at 10 months stage (\%) & 0.13 & 0.18 & 2.74 & 3.31 & 68.26 & 4.66 \\
\hline 19 & CCS at 8 months stage (\%) & 1.96 & 2.15 & 15.57 & 16.30 & 91.22 & 30.63 \\
\hline 20 & CCS at 10 months stage (\%) & 0.46 & 0.66 & 6.12 & 7.33 & 69.79 & 10.54 \\
\hline 21 & Pol In cane at harvest (\%) & 0.50 & 0.67 & 5.36 & 6.20 & 74.65 & 9.54 \\
\hline 22 & Sugar yield at harvest (t/ha) & 1.90 & 2.63 & 15.03 & 17.70 & 72.06 & 26.27 \\
\hline 23 & Cane yield at harvest (t/ha) & 76.11 & 117.14 & 10.61 & 13.16 & 64.97 & 17.62 \\
\hline
\end{tabular}

GAM - Genetic Advance as percent of mean

In conclusion, high heritability coupled with high genetic advance as percent of means was observed for germination percent, cane diameter at harvest, pol in juice at 8 month stage, CCS at8 month and sugar yield at harvest suggesting the preponderance of additive genetic effect in the determination of these characters. It also indicated that selection for these characters will be effective for future improvement of clones. However, high heritability with moderate genetic advance as percent of mean was observed in plant height at 240 days and at harvest single cane weight, number of shoots, single cane weight, millable cane at harvest, brix percent at 8 month, CCS at 10 month and cane yield at harvest indicating the role of dominant genetic effects in determination of these characters and it require careful selection for the desired improvements in the characters.

\section{Acknowledgement}

Authors are thankful to Sugarcane Research Institute Pusa, Samastipur for providing early maturing sugarcane clones and all the members of Department of Plant Breeding and Genetics of RPCAU Pusa for their support and providing necessary facilities.

\section{References}

Anshuman, S., P. K. Bhatnagar., Khan, A. Q. and Shrotria, P. K. (2002). Variability and heritability for cane yield, its components and quality characters in sugarcane (Saccharum spp complex). Indian. Sug. J., 53(4): 717719.

Bairwa, A.K., Ram, R., Neetu., Jeena, A. S., Singh K. and Singh S. P. (2017). 
Estimation of the Extent of Variability for Different Morphological and Juice Quality Characters Among Early Generation Sugarcane Clones. Int.J.Curr.Microbiol.App.Sci. 6(2): 12721278 .

Bhatnagar, P. K., A. Q. Khan, A. Singh and K. A. Khan (2003). Studies on genetic variability, heritability and genetic advance in plant and ratoon crops of sugarcane. Indian Sugar, 53(3): 183-185.

Burton, G. W. and De Vane (1953). Estimating heritability in tall Fescue from replicated clonal material. Agron. J. 45: 475 - 481

Chandrakant; Ravikant and Singh, P. K. (2007). Screening criteria for selection of superior clones in early clonal generation of Saccharum complex hybrids. Crop Improvement. 34(1): 63-71.

Doule, R. B. and Balasundaram, N. (2002). Genetic variability in sugar yield and its components for selection of sugarcane. Journal of Maharashtra Agricultural Universities. 27(3): 326-327.

Falconer, D. S. (1989). Introduction to quantitative genetics. $3^{\text {rd }}$ edition Longman. New York.

Fisher, R. A. and Yates, F. (1938). Statistical tables for Biological, Agricultural and Medical Research.

Johnson, H. W., Robinson, H. F. and Comstock, R. E. (1955a). Estimates of genetic and environmental variability in soybeans. Agron. J. 47: 314 - 318.

Khalid, M., Rahman, H., Rabban, A., Farahatullah and Khan (2014). Qualitative and quantitative assessment of newly selected sugarcane Sarhad J. Agric. Vol. 30, No. 2.

Khan, I. A., S. Bibi, S. Yasmin, A. Khatri and N. Seema. 2013. Phenotypic and genotypic diversity investigations in sugarcane for drought tolerance and sucrose content. Pak. J. Bot. 45(2): 359-366

Kumar, P., Kumar, B. and Chandra K. (2017).
Estimation of Extent of Variability for Various Productive Traits in Sugarcane under Water-Logged Condition. Int.J.Curr.Microbiol.App. Sci (2017) 6(7): 1187-1192

Nair, N. V. and Somarajan, K. G. and Balasundaram, N. (1980). Genetic variability, heritability and genetic advance in S. officinarum L. Inter. Sugar. J. 82(981): 275-276.

Panse, V. G. and Sukhatme, P. V. (1967). Statistical methods of agricultural workers $2^{\text {nd }}$ edn. pp. 381, ICAR, Publication, New Delhi.

Rahman, M. M. and Bhuiyan, M. S. R. (2009). Variability, heritability and genetic advanced for cane yield and its components in some indigenous and exotic promising clones of sugarcane (Saccharum officinarum L). Indian Sugar. 59(2): 35-42.

Ravishankar, C. R., Ramappa, H. K., Prakash, P., Swamygowda, S. N., Shivakumar, N. and Usha Ravindra (2004). Sugarcane associated characters for higher sugar yield. Environment and Ecology. 22(Spl3): 536-539.

Singh, M. K., Pandey, S. S., Kumar, R. and Singh, A. K. (2010). Estimation of genetic variability, heritability and genetic advance in mid-late maturing clones of sugarcane. Environment and Ecology. 28(4): 2301-2305.

Sabitha, N., Rao, K. P., Rao, C. P. and Rao, M. S. (2007). Genetic variation, heritability and genetic advance for yield components in sugarcane. Sugar Tech. 9(4): 290-292

Spencer, G.L. and Meade,G.P.1955.Cane Sugar H and Book. Wiley and Sons, N.Y.

Tyagi, V.K., Sharma, Satish and Bhardwaj, S. B. (2011). A study on the nature and magnitude of variations in different traits in sugarcane. Electronic Journal of Plant Breeding. 2(3): 334-341.

\section{How to cite this article:}

Praveen Kumar, S.S. Pandey, Balwant Kumar, D.N. Kamat and Mahesh Kumar. 2018. Genetic Variability Study for Yield and Associate Characters in Early Maturing Sugarcane. Int.J.Curr.Microbiol.App.Sci. 7(07): 3254-3260. doi: https://doi.org/10.20546/ijcmas.2018.707.379 